\title{
Phosphorus export from catchments: a global view
}

\author{
M. Alvarez-Cobelas ${ }^{1}$ AND S. Sánchez-Carrillo ${ }^{2}$ \\ Higher Council of Scientific Research-Institute of Natural Resources, Serrano 115 dpdo. \\ E-28006 Madrid, Spain \\ D. G. Angeler ${ }^{3}$ \\ Swedish University of Agricultural Sciences, Department of Aquatic Sciences and Assessment, \\ P.O. Box 7050, SE-750 07 Uppsala, Sweden, and Institute of Environmental Sciences, \\ University of Castilla-La Mancha, Av. Carlos III s/n., E-45071 Toledo, Spain
}

\author{
R. Sánchez-Andrés ${ }^{4}$ \\ Higher Council of Scientific Research-Royal Botanical Garden, Pza. Murillo 2, E-28014 Madrid, Spain
}

\begin{abstract}
We reviewed global P export and its controlling factors from 685 world rivers. We used available continuous (runoff, rainfall, catchment area, $\%$ land use, and population density) and discrete (runoff type, soil type, biome, dominant land use, dominant type of forest, occurrence of stagnant water bodies in catchment, and Gross Product per Capita [GPC]) variables to predict export of $\mathrm{P}$ fractions. $\mathrm{P}$ export $\left(\mathrm{kg} \mathrm{P} \mathrm{km}^{-2} \mathrm{y}^{-1}\right)$ spanned 6 orders of magnitude worldwide. The distribution of all fractions of $\mathrm{P}$ export (total P [TP], soluble reactive P [SRP], and nonSRP [dissolved organic and particle-bound P]) was right skewed. Export of nonSRP had the highest coefficient of variability, and nonSRP was the dominant part of export. The available environmental variables predicted global $\mathrm{P}$ export fairly well $\left(R^{2}=0.73\right)$ if total $\mathrm{N}$ export was included in calculations. The unexplained variance in $\mathrm{P}$ export might be attributed to noise in the data set, inaccuracy of measurements of environmental variables at fine scales, lack of quantitative data on anthropogenic $\mathrm{P}$ sources, insufficient knowledge of $\mathrm{P}$ behavior in catchment soils, and nonlinearity of controlling processes. $\mathrm{P}$ exports were highly variable among catchment types, and runoff and population density were the predictors shared by most models. P export appeared to be controlled by different sets of environmental variables in different types of catchments. Quasi-empirical, mechanistic models of $\mathrm{P}$ export performed better than did empirical models. Our mechanistic understanding of $\mathrm{P}$ export could be improved by refining current analytical methods to obtain fast and reliable values of all $\mathrm{P}$ fractions in aquatic ecosystems and by incorporating better and more detailed data on catchment features, anthropogenic sources of $\mathrm{P}$, and instream variables in a mechanistic modelling framework.
\end{abstract}

Key words: environmental factors, regional approaches, in-stream processes, modelling.

Many studies on freshwater P dynamics have been published since the seminal paper by Vollenweider (1968), and these studies have contributed much to our knowledge of problems related to eutrophication problems of aquatic ecosystems (Schindler 2006). The overall picture of control of eutrophication by $\mathrm{P}$ supply is more complex than previously thought (Lewis and Wurtsbaugh 2008, Schindler et al. 2008).

\footnotetext{
${ }^{1}$ E-mail addresses: malvarez@ccma.csic.es

2 sanchez.carrillo@ccma.csic.es

3 david.angeler@vatten.slu.se

${ }^{4}$ rsanchez@rjb.csic.es
}

The biological relevance of $\mathrm{P}$ in aquatic ecosystems is relatively well understood, but fewer studies have described patterns and processes of $\mathrm{P}$ export from terrestrial to marine ecosystems at the global scale (Meybeck 1982, Howarth et al. 1995, Smith et al. 1997, Smith et al. 2003, 2005, Turner et al. 2003). The landsea connection via rivers is an important component in global P biogeochemistry. A quantitative picture of components of exports and environmental characteristics that mediate these exports is essential to our understanding of global $\mathrm{P}$ transport. Consideration that human activities affect these exports is especially relevant because $\mathrm{P}$ transport via rivers has increased 
TABle 1. List of Appendices and sources of data in each. NEST = Baltic Nest Institute at Stockholm (Sweden) and Aarhus (Denmark).

\begin{tabular}{|c|c|c|c|}
\hline Appendix & Data type & Data sources & Comment \\
\hline 2 & $\begin{array}{l}\text { Environmental data recorded for } \\
\text { world-wide catchments in the } \\
\text { compiled studies }\end{array}$ & $\begin{array}{l}\text { USA: water.usgs.gov/nawqa/nutrients/datasets } \\
\text { Victoria, Australia: www.vicwaterdata.net/ } \\
\text { vicwaterdata } \\
\text { Baltic NEST: data.ecology.su.se/models/bed.htm }\end{array}$ & \\
\hline
\end{tabular}

since prehistoric times, mainly as a result of human activities (Schlesinger 2001, MacKenzie et al. 2002).

Model-based predictions of $\mathrm{P}$ export from catchments using easily measured, environmental variables have been moderately successful on a regional scale (Behrendt and Opitz 2000, Smith et al. 1997). However, models based on global-scale analyses do not appear to be very strong (Smith et al. 2005). This difference could arise from several problems, including accuracy of landuse assessment, accuracy of measurements of environmental variables at the catchment scale, and insufficient knowledge of $\mathrm{P}$ interaction with catchment soils. For example, the linkage between soil P sorption (mainly onto colloids in the soil matrix; McGechan and Lewis 2002) and its export to nearby streams has been substantially less well studied than the linkage for soil $\mathrm{N}$ sorption (Bennett et al. 2001). Also, the dynamics of Ca-P complexes in the soil matrix are not well known (Frossard et al. 1995). Furthermore, many studies have reported only a single P fraction (Marchetti and Verna 1992, Moss et al. 1992, Behrendt and Opitz 2000, Smith et al. 2005), which limits our understanding of export behavior of other P fractions. Moreover, many broadscale studies are restricted to temperate areas (Cooke and Prepas 1998, Donnelly et al. 1998, Mulholland 2004), and this geographic bias limits our ability to identify mechanisms that control $\mathrm{P}$ dynamics at global scales (Harris 2001).

We compiled a data set for $\mathrm{P}$ export by streams and rivers (Table 1, Appendix 1; available online from: http://dx.doi.org/10.1899/09-073.1.s1) to assess which environmental factors best predict $\mathrm{P}$ export from the world's rivers. We considered runoff (Sharpley et al. 1995), soil type (Gardner 1990), landuse practices (Sharpley et al. 1992), wetlands (DeVito et al. 1989), and human population density (Smith et al. 2003, 2005). $\mathrm{P}$ export from catchments is controlled by environmen- tal factors, and regional-scale environmental factors best explain variability of $\mathrm{P}$ export (Behrendt and Opitz 2000). These factors also might be relevant at the global scale. Last, comparisons among some studies carried out in countries with contrasting Gross Product per Capita (GPC) (Lesack et al. 1984, Stålnacke et al. 1999) suggest that catchment-derived $P$ is lower in countries with lower GPC, possibly because water consumption and use of $\mathrm{P}$ detergents are usually much higher in developed countries (Postel 1992, Brenner 1988) and increase P export from catchments. Thus, GPC could further explain catchment $P$ export, but its role has not been assessed.

Modelling of $P$ export has been attempted at regional and worldwide scales to enable predictions of $\mathrm{P}$ export to the oceans and retention within catchments. Development of these models is a critical step toward a synthetic understanding of the global $\mathrm{P}$ biogeochemical cycle. Some predictive models of $P$ export that rely mostly on empirical approaches have been proposed (Smith et al. 1997, Behrendt and Opitz 2000, Smith et al. 2003, 2005, Turner et al. 2003, Harrison et al. 2005a, b), but they have not yet been compared.

Therefore, we decided to review the still increasing information on $\mathrm{P}$ export from catchments and to compare the available predictive models to ascertain whether they are useful on their own or need further improvement. Our goals were to compile a global data set on total and dissolved P export, to model it empirically as a function of easy-to-obtain variables, and to compare our models with previously reported models. We used discrete and continuous environmental variables (e.g., catchment area, rainfall, runoff, soil type, biome, land use, population density, and GPC) and evaluated the predictability of P exports. A global-scale analysis might be too coarse and could obscure effects resulting from certain environmental conditions. Therefore, we also tested how well $\mathrm{P}$ 


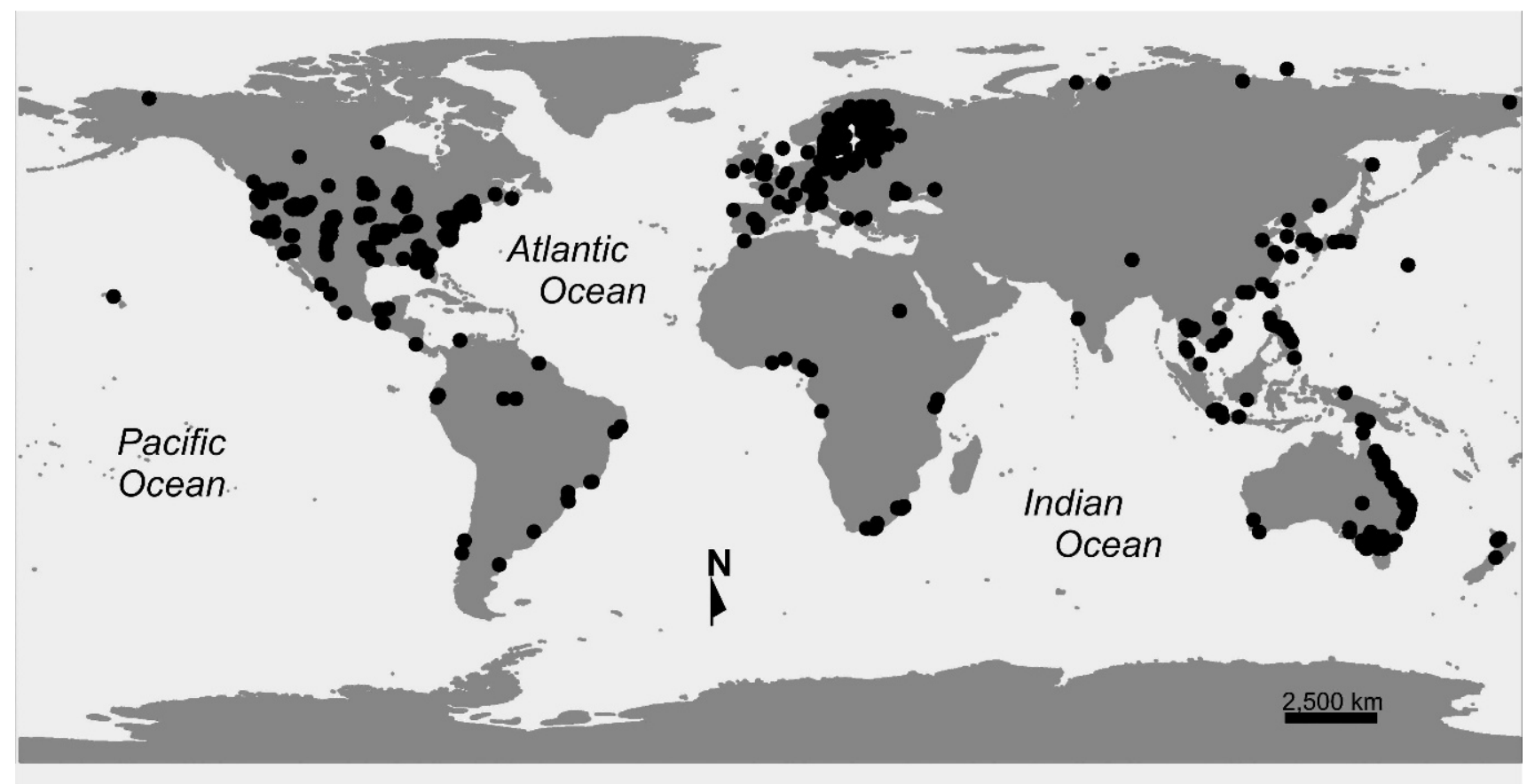

FIG. 1. Catchments from which P export data used in our study were obtained (Appendix 1).

exports could be predicted for catchments grouped on the basis of environmental characteristics (runoff, land use, soil type, biome, and GPC). We used multivariate regression to model $\mathrm{P}$ export.

\section{Methods}

Annual total P export by streams has been measured in catchments between lat $76^{\circ} \mathrm{N}$ and $43^{\circ} \mathrm{S}$. North America and Africa were the best- and the leaststudied continents, respectively (Fig. 1). Our review is based on data from the literature and web sources that were available before January 2007 (Tables 1, 2). We express $\mathrm{P}$ exports as the quantity of $\mathrm{P}$ that is exported by rivers on an annual basis $\left(\mathrm{kg} \mathrm{P} \mathrm{km}^{-2} \mathrm{y}^{-1}\right)$. We included total $\mathrm{P}$ (TP) and soluble reactive $\mathrm{P}(\mathrm{SRP})$ in the data set when they were available. We considered 685 catchments, but information on the export of $\mathrm{P}$ fractions and its controlling factors was highly variable among catchments. The fractions ortho-P, poly- $\mathrm{P}$, and dissolved organic and particulate P (Golterman 2001) cannot be measured accurately chemically because available methods limit measurement of particlebound $\mathrm{P}$ (including organic and inorganic forms). Therefore, data on these fractions in worldwide literature are few and incomplete, and analysis of these fractions was not feasible. However, when both TP and SRP were reported for catchments, we used subtraction to calculate the nonSRP fraction (the sum of dissolved organic and particulate forms).
We compiled available information on annual discharge; rainfall; runoff, catchment area; percentages of cropland, forests, urban areas, range lands, stagnant habitat, and pasture; and population number and density (Table 1, Appendix 2; available online from http://dx.doi.org/10.1899/09-073.1.s2); and several discrete variables, including runoff regime (xeric [runoff $<100 \mathrm{~mm} / \mathrm{y}$ ] vs mesic catchments), landuse/land-cover type (LULC; $80 \%$ of overall catchment area in a specific LULC type), forest type (coniferous and deciduous; tropical forests were excluded from the analyses because of insufficient data), and presence/absence of stagnant water bodies in the catchment. LULC was limited to cropland, forest, pasture, and range land based on data supplied by authors of each study. We classified catchments with $>6 \%$ impervious surface as urban; this percentage has been suggested as a threshold for dramatic decrease in aquatic biodiversity (Morse et al. 2003). Other empirical data that can be useful for empirical modelling (e.g., anthropogenic inputs, such as wastewater discharge and other point and diffuse sources) were available in too few studies to allow meaningful analyses.

We retrieved information concerning soil types, biomes, and GPC (Table 1, Appendix 3; http://dx. doi.org/10.1899/09-073.1.s3) from FAO (2003), Olson et al. (2001), and International Monetary Fund (2000). We acknowledge that this information is only a rough index for specific catchments because the scale of 
TABle 2. Studies in which dissolved organic and total particulate $\mathrm{P}$ export have been reported. TP $=$ total $\mathrm{P}, \mathrm{SRP}=$ soluble reactive $\mathrm{P}, \mathrm{DOP}=$ dissolved organic $\mathrm{P}, \mathrm{PP}=$ particulate $\mathrm{P}$.

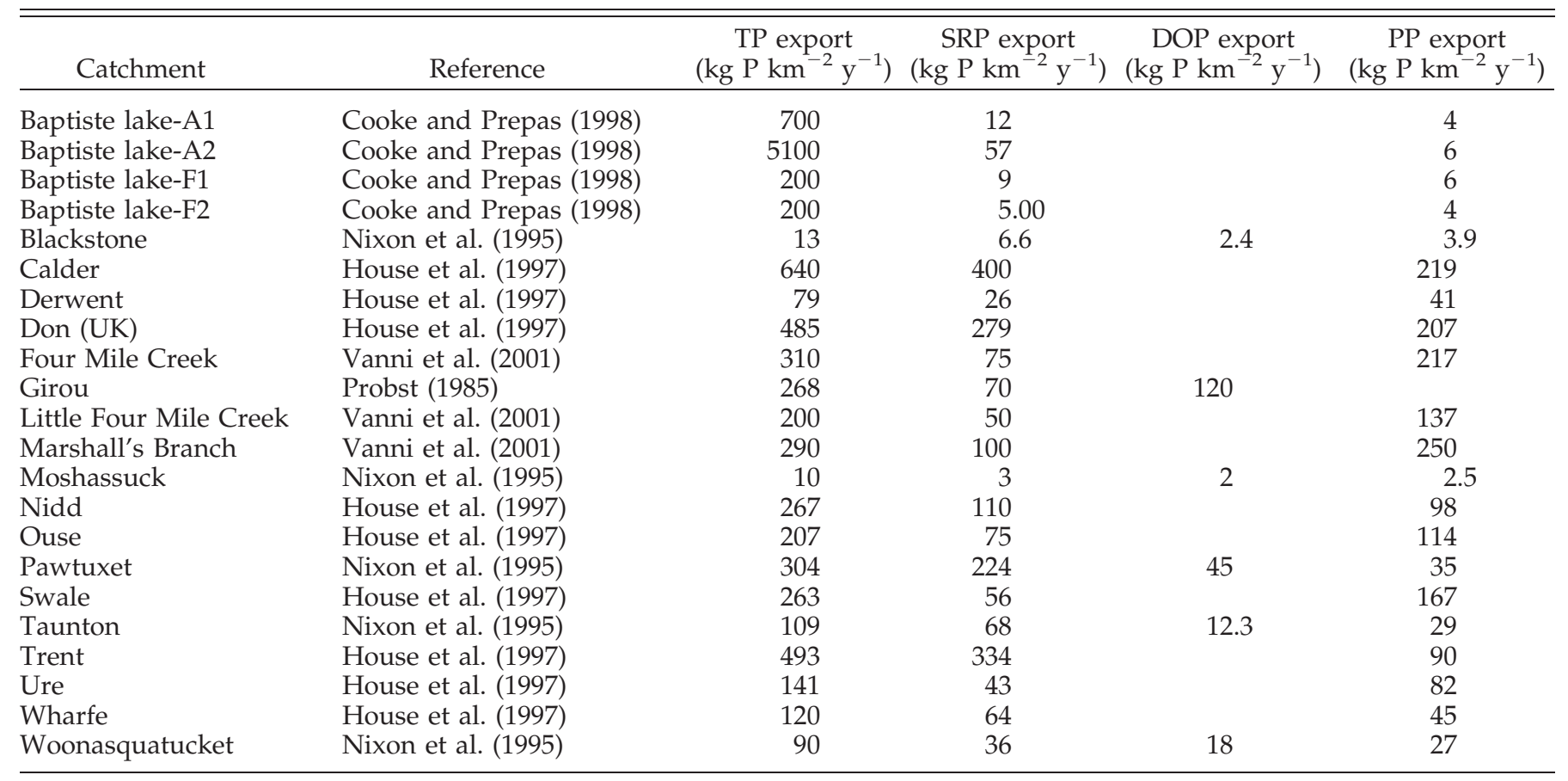

world maps is usually too coarse to be catchmentspecific, and large catchments usually contain different soils, GPC, and even biomes. Soil types belonged to 21 different categories sensu FAO (2003): acrisols, arenosols, cambisols, chernozems, ferralsols, gleysols, histosols, kastanozems, lithosols, luvisols, nitosols, phaeozems, planosols, podzols, podzoluvisols, regosols, rendzinas, solonetzs, vertisols, xerosols and yermosols. Biomes were arranged in 8 categories (Olson et al. 2001): boreal forests/taiga; deserts and xeric shrublands; Mediterranean forests, woodlands, and scrub (Mediterranean habitats); temperate broadleaf and mixed forests (temperate deciduous forests); temperate coniferous forests; temperate grasslands, savannas, and shrublands; tropical and subtropical grasslands, savannas, and shrublands; and tropical and subtropical moist broadleaf forests. We defined 7 levels of GPC (in US\$) (International Monetary Fund 2000): 1000 to 3000,3000 to 5000,5000 to $10,000,10,000$ to $15,000,15,000$ to $20,000,20,000$ to 30,000 , and $>30,000$. However, we evaluated only SRP export with GPC data because few data exist for TP export in areas with low GPC. Several categories of discrete variables contained very few data, and we were unable to analyze them further. Therefore, we combined GPC levels $<10,000$ to obtain enough data to compare $\mathrm{P}$ export from catchments in areas of low economic development with $\mathrm{P}$ export from catchments in areas of higher economic development.
Most data were strongly right-skewed. Therefore, we chose a nonparametric approach for preliminary statistical analysis and used Mann-Whitney and Kruskal-Wallis tests (Siegel and Castellan 1988) to compare medians of categories within runoff regime, soil type, biome, LULC, and GPC. When data from the same catchment were available for different years, only those data from the year with the most available $P$ export and environmental variables were used to avoid overweighting information from the best studied areas in the worldwide data set. We did all statistical analyses with STATISTICA (version 6.1; StatSoft, Tulsa, Oklahoma).

We correlated the export of $\mathrm{P}$ fractions with the quantitative environmental variables to estimate the environmental control of $\mathrm{P}$ export from the world's catchments, and we calculated the coefficient of determination $\left(R^{2}\right)$ to deduce the explanatory power of significant relationships. We also modelled total $\mathrm{P}$ export with stepwise multiple regressions. We used $\log (x)$-transformed data to stabilize variances and because we assumed that nutrient export was affected by nonlinear processes. These regression models were based on data covering the global scale. We used additional models to test for effects within runoff regime (mesic vs xeric), soil type, biomes, LULC types, and GPC levels. We used stepwise forward selection to develop multivariate models with meaningful, statistically independent predictor variables. 
We initially identified best models on the basis of model fit (adjusted $R^{2}$; Neter et al. 1996). However, stepwise regression has been criticized on the grounds that it: 1) produces bias in parameter estimates, 2) provides inconsistencies among model selection algorithms, 3) generates problems in multiple hypothesis testing, and 4) inappropriately focuses on a single best model (Whittingham et al. 2006). Use of adjusted $R^{2}$ as a criterion allows overfitted models, and hence, information-theoretic analysis is a better way to compare models (Burnham and Anderson 2002). Previously reported models of $P$ export used adjusted $R^{2}$ as an index of goodness of fit (Smith et al. 1997, Smith et al. 2003, 2005, Turner et al. 2003), so we have provided adjusted $R^{2}$ values when comparing predictive models.

Akaike Information Criterion (AIC) is a heuristic approach that provides a straightforward and meaningful way to rank models based on their goodness of fit. AIC reflects the precision and complexity of the model, and therefore, is a better tool for model selection (Burnham and Anderson 2002). We used AIC to compare our models based on the same data sets and dependent variables (because the inference is conditional on the data at hand; Burnham and Anderson 2002). We estimated models only if $\geq 20$ catchments in a given category had the required environmental predictor variables, and we chose models with the lowest AIC values from among those based on the same dependent variables and data sets. Thus, we built many models for different dependent variables and data sets, but present only one for a given group of dependent variables and data. The number of models tested for each group ranged from 3 to 31, depending on degrees of freedom. We used the $2^{\text {nd }}$-order information criterion, which accounts for small sample size, to compare models with different dependent variables (Burnham and Anderson 2002).

We overcame problems related to multicolinearity in the models by excluding from analysis variables that were correlated (Legendre and Legendre 1998). The case of runoff was particularly troublesome because runoff is included in the calculation of $\mathrm{P}$ export and, thus, could cause spurious correlation. Methods do exist to overcome this drawback (Prairie and Bird 1989), but most studies of nutrient export do not eliminate the problem and still provide insightful results. However, we cannot eliminate the possibility that $\mathrm{P}$ export and runoff shared a large measurement term, a statistical constraint on calculating correlation between runoff and P export (Prairie and Bird 1989). Therefore, we also conducted multiple regressions with volumetric TP, SRP, and nonSRP concentration to eliminate the role of export in the dependent variable.

\section{Results}

P export

Annual TP export varied a million-fold from 0.008 to $5100 \mathrm{~kg} \mathrm{P} \mathrm{km}^{-2} \mathrm{y}^{-1}(n=527 ;$ Appendix 1$)$. Annual SRP export was 0.007 to $2074 \mathrm{~kg} \mathrm{P} \mathrm{km}^{-2} \mathrm{y}^{-1}(n=558)$. In catchments with data for TP and SRP, nonSRP export was 0.004 to $5043 \mathrm{~kg} \mathrm{P} \mathrm{km}^{-2} \mathrm{y}^{-1}(n=397)$, and was $59 \pm 22 \%$ (mean \pm SD) of TP export. P export data were right skewed (Fig. 2A-C), with coefficients of variation (CVs) of 364, 306, and 547\% for TP, SRP, and nonSRP export, respectively.

Few studies provided export data for other $\mathrm{P}$ compounds, such as dissolved and particulate $\mathrm{P}$ and poly-P compounds (Table 2). Dissolved organic $\mathrm{P}$ accounted for $22 \pm 12 \%$ of TP export, whereas particulate P was usually $36 \pm 25 \%$ of TP export in temperate catchments. This variability might have arisen from our use of a mixed data set that included human-influenced and pristine catchments. Thus, particulate $\mathrm{P}$ export might be higher than dissolved organic P export. However, this result only pertains to some temperate catchments.

TP export was lower in xeric than in mesic catchments (Mann-Whitney test, $p<0.05$; Fig. 3A), but the $\mathrm{CV}$ was higher for xeric than for mesic catchments. SRP export was almost $9 \times$ higher in mesic than in xeric catchments, and mesic and xeric catchments had similar CVs. P export increased along a gradient of soil type (cambisols $<$ podzols $<$ acrisols $<$ luvisols) (Kruskal-Wallis test, $p<0.05$; Fig. 3B), but $\mathrm{CVs}$ were high for all soil types. $\mathrm{P}$ export was lower in boreal forest/taiga and deserts and xeric shrublands than in the remaining biomes, and was higher in tropical than in temperate biomes (Kruskal-Wallis test, $p<0.05$; Fig. 3C). P export was far more variable among biomes (CVs from $61 \%$ in boreal forests/taiga to $547 \%$ in grasslands) than among runoff regimes (CVs from 302 to 509\%) or soil types (CVs from 197 to 284\%).

TP export was higher in catchments where cropland was the predominant LULC type than in catchments with other LULC types. TP export was $2 \times$ higher in cropland than in pasture and $5 \times$ higher in cropland than in forest (Kruskal-Wallis test, $p<$ 0.05; Fig. 3D). SRP export was $4 \times$ higher in cropland than in forest (insufficient data for pasture for meaningful comparison). TP export was higher in coniferous than in deciduous forest (Mann-Whitney test, $p<0.05$; Fig. 3E) (insufficient SRP data for meaningful comparison among forest types). 

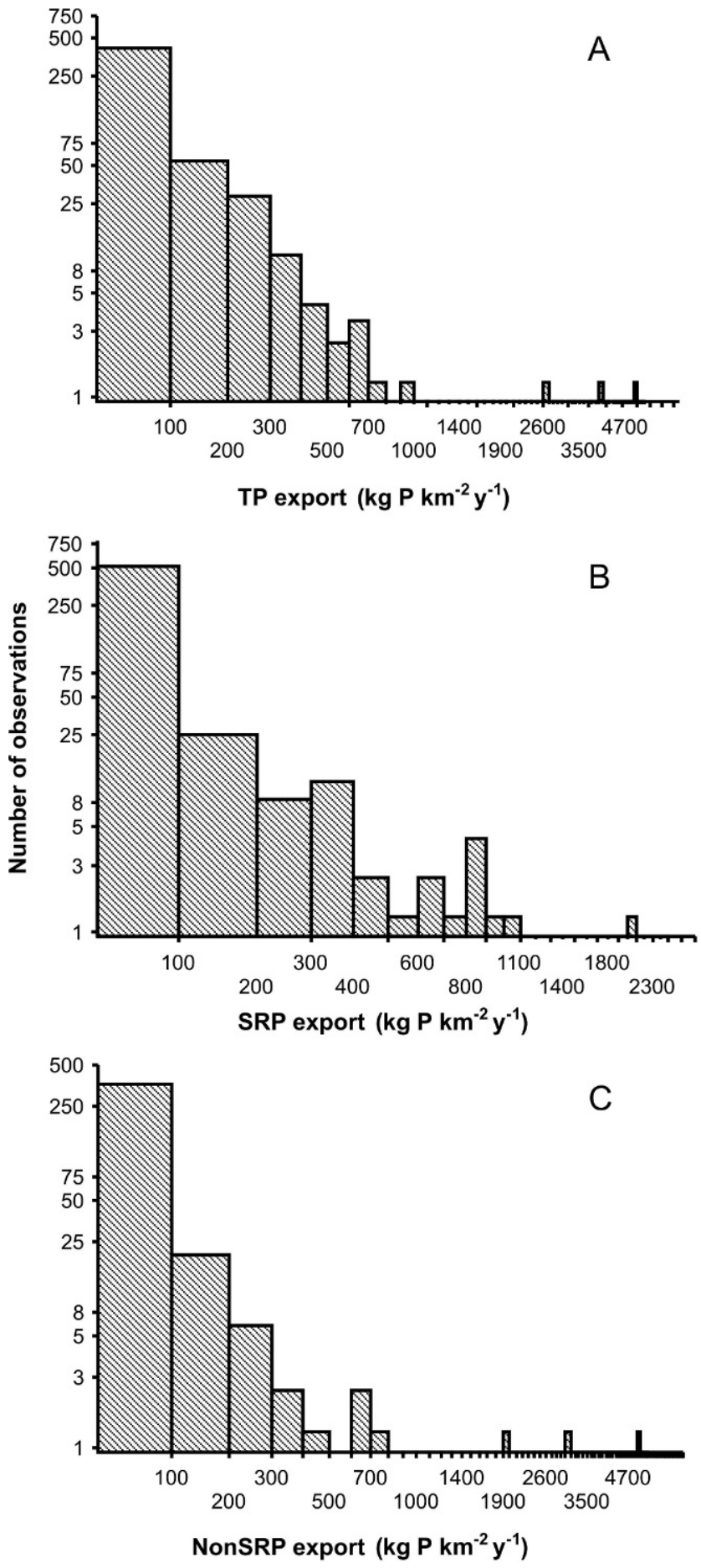

FIG. 2. Histograms of global catchment total P (A), soluble reactive $\mathrm{P}(\mathrm{SRP})(\mathrm{B})$, and nonSRP $(\mathrm{C})$ export rates. nonSRP = remaining $\mathrm{P}$ after subtracting $\mathrm{SRP}$ from total $\mathrm{P}$ (i.e., organic and particle-bound inorganic $\mathrm{P}$ ). Note logarithmic scales on all axes.

TP export was less variable in catchments with stagnant water bodies (lentic systems including wetlands, lakes, etc.) than in catchments without them, but their medians were not statistically different
(Mann-Whitney test, $p>0.05$; Fig. 3F). SRP export was lower in catchments with stagnant water bodies than in catchments without them (Mann-Whitney test, $p<0.05)$. SRP export was greater and more variable in catchments with $<\$ 10,000$ GPC than in catchments with higher GPC (Kruskal-Wallis test, $p<$ 0.05; Fig. 3G).

\section{Factors controlling $P$ export}

TP export was weakly related to SRP export $\left(R^{2}=\right.$ $0.42, p<0.05)$. NonSRP export covaried strongly with TP export $\left(R^{2}=0.96, p<0.05\right)$ and with SRP export, but the relationship was much weaker $\left(R^{2}=0.25, p<\right.$ 0.05). The relationships of nonSRP with qualitative and quantitative environmental factors were similar to those for TP because nonSRP export was tightly linked to TP export.

Neither TP nor SRP export was correlated with annual discharge or rainfall (Spearman rank correlation, $p>0.05)$. TP and nonSRP export were weakly correlated with population density $\left(R^{2}=0.12, p<\right.$ $0.05)$, but not with number of inhabitants $(p>0.05)$, and their relationships with LULC, when statistically significant, were even weaker $\left(R^{2}<0.05, p<0.05\right)$. SRP export was weakly correlated with $\%$ pasture $\left(R^{2}\right.$ $=0.04, p<0.05)$, and its correlations with the remaining environmental predictors were even weaker. Hence, P export was weakly correlated with single environmental predictors.

Relationships between P export and environmental variables were better resolved with multivariate statistics. Models of TP export explained $\sim 1 / 2$ of the total variability with 3 environmental predictors, and the variance explained increased to $73 \%$ when total $\mathrm{N}$ export was included in the model (Table 3). However, this improvement might have been the result of the frequently observed strong correlation between particulate $\mathrm{N}$ and P. SRP export was weakly explained by runoff and population density. However, the predictive power increased when the \% stagnant habitat was added as an independent variable (Table 3). NonSRP export also was weakly explained by multivariate models. Only runoff, \% cropland, and \% stagnant habitat were significant predictors (Table 3). Runoff was not a significant predictor when we used nonSRP concentration instead of export as the dependent variable to avoid spurious correlation (Table 3). The variance explained by multivariate models was lower for $\mathrm{P}$ concentration than for $\mathrm{P}$ export.

We tested multivariate models within discrete categories of runoff regime, soil type, biomes, LULC, and GPC. TP export in mesic catchments was strongly predicted by a combination of catchment area, runoff, 
$\%$ urban and $\%$ pasture, and population density (Table 4). TP export in xeric catchments was explained only by population density, but the explained variance was low. TP export in catchments with cambisols and luvisols was strongly predicted by population density, and when \% cropland was included the explained variance increased $2 \times$ (Table 4). TP export in catchments with podzols was predicted by runoff and \% cropland. The variance explained by environmental predictors in biomes ranged from $33 \%$ (temperate deciduous forests) to $76 \%$ (Mediterranean habitats). Runoff and \% forest were important predictors in 3 biomes. $\mathrm{P}$ export in Mediterranean habitats was influenced by $\%$ pasture and population density, whereas $\mathrm{P}$ export in boreal forests/taiga depended on $\%$ range land and \% stagnant habitat (Table 4). In agricultural catchments, $55 \%$ of overall variability in TP export was explained by runoff and $\%$ cropland, but the explained variance decreased to $40 \%$ in forested catchments, where runoff and \% stagnant habitat were the main predictors (Table 4). TP export in urban catchments was predicted only by population density, but explained variance was only $27 \%$. Slightly $<1 / 2$ of total variability in $\mathrm{P}$ export in catchments with and without stagnant water bodies could be explained by environmental predictors, but more predictors were needed in catchments with stagnant water bodies than in catchments without them. Runoff was an important predictor variable in both types of catchments (Table 3). SRP export in catchments where GPC was $>\$ 20,000$ was partly explained by runoff, but population density was an important predictor when GPC was $\$ 20,000$ to $\$ 30,000$, and \% cropland became important when GPC was $>\$ 30,000$. Explained variance decreased when GPC was $>\$ 30,000$ (Table 4).

To summarize, $\mathrm{P}$ export was predicted by different sets of environmental variables as a function of catchment-specific environmental characteristics. Runoff and population density were the best predictors in these models.

\section{Discussion}

P export

TP and SRP export from the world's catchments spanned 6 orders of magnitude, and the nonSRP fraction was the most variable export of the 3 fractions (Fig. 2A-C, Table 2). NonSRP was the dominant form of $\mathrm{P}$ export in our global-scale evaluation, as observed by Donnelly et al. (1998) in Australia. NonSRP is a relatively broad category that includes various forms of dissolved and particulate $\mathrm{P}$ fractions. Future studies should discriminate among these fractions, provided that chemical methods for measuring $\mathrm{P}$ fractions are improved (Golterman 2001). For example, inorganic particle-bound $\mathrm{P}$ could be the dominant form of export in clay-rich landscapes that are subject to strong soil erosion as a result of frequent storms (Donnelly et al. 1998), but the dominant P fraction in TP export is not always clear in other catchment types. More studies will be needed to address the issue of export of $\mathrm{P}$ fractions, particularly in tropical and boreal catchments (Table 2).

Many catchment characteristics influenced $\mathrm{P}$ export. In general, features that increased spatial and temporal heterogeneity tended to influence $\mathrm{P}$ export rates. Xeric catchments exported less $\mathrm{P}$ than mesic catchments (Fig. 3A), but variability in $\mathrm{P}$ export was higher in xeric than in mesic catchments. Increased retention of nutrients and higher variability of export rates in xeric catchments might be associated with combined effects of endorheic phenomena, which concentrate $\mathrm{P}$ in closed catchments, and higher interannual variability in precipitation (Caraco and Cole 2001), which can cause flash floods that cause P export rates to change. Soil type had little effect on $\mathrm{P}$ export, except that $\mathrm{P}$ export was much greater in catchments with luvisols (Fig. 3B), which are heterogeneous and consist of a wide array of soils with contrasting properties (FAO 2003). P export was most variable in Mediterranean habitats and temperate grasslands and shrublands (Fig. 3C), perhaps because: 1) Mediterranean habitats consist of a wide range of habitat types; 2) temperate grasslands and shrublands often are in various stages of recovery from agricultural landuse, and their ecological condition can vary depending on the time elapsed since agricultural abandonment; and 3) both biomes have long histories of landuse change (Grove and Rackham 2001). Thus, export of $P$ derived from soils and human activity (including wastewater discharge) is likely to be more variable in these biomes than in others.

As has been observed in other studies (Cooke and Prepas 1998, Pieterse et al. 2003), far more P was exported from catchments with high \% cropland than from catchments dominated by pasture or forest (Fig. 3D). Agricultural land use is associated with $\mathrm{P}$ fertilization and increased soil erosion caused by tilling (Sharpley et al. 1995). Less P was exported from deciduous than from coniferous forests (Fig. 3E), a result consistent with the fact that coniferous forests appear to export more dissolved nutrients than deciduous forests (Lovett et al. 2000).

High \% stagnant habitat increased retention of SRP, but not $\mathrm{TP}$, in catchments, and decreased the variability of TP export (Fig. 3F). This pattern differs 

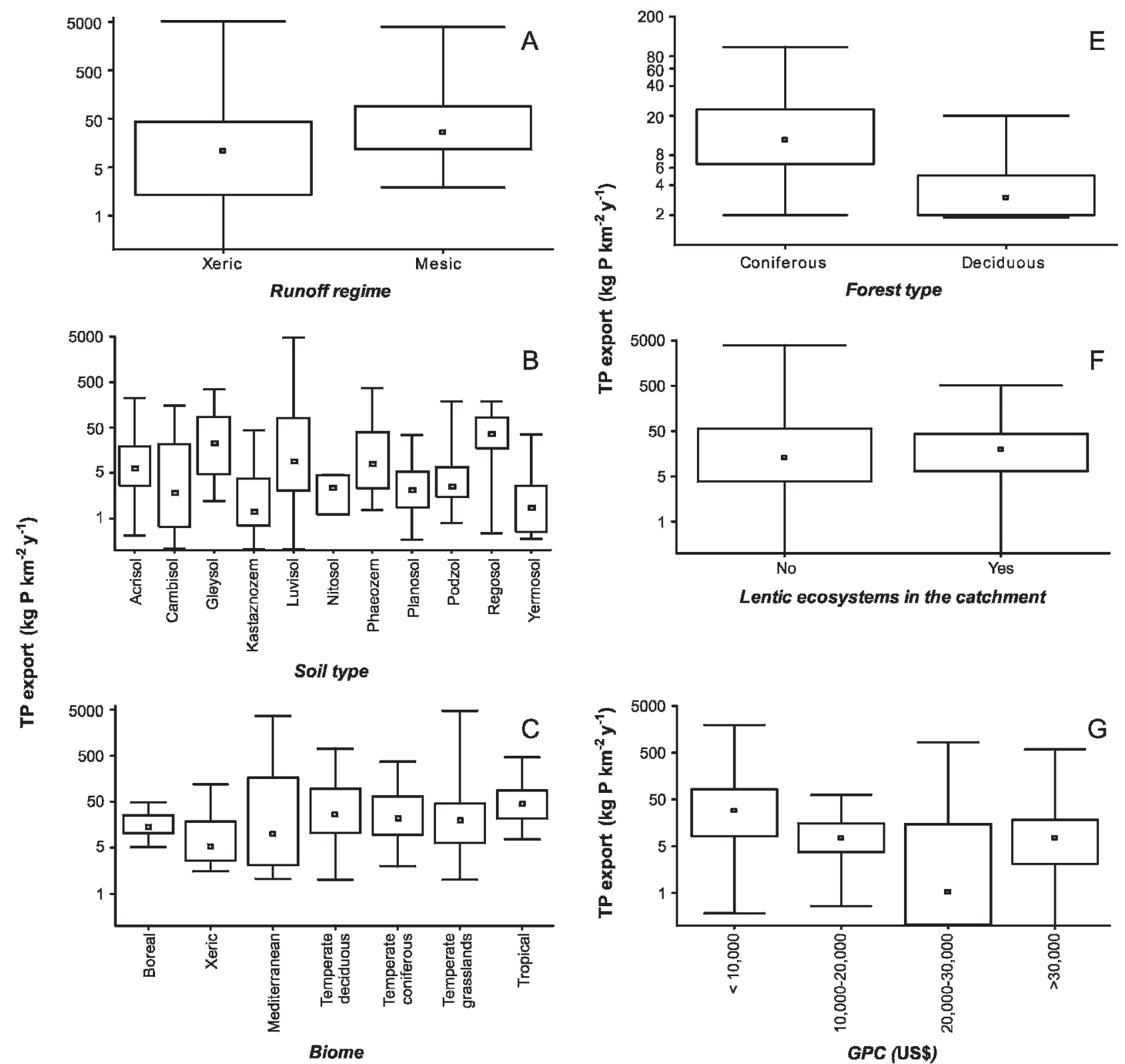

Lentic ecosystems in the catchment
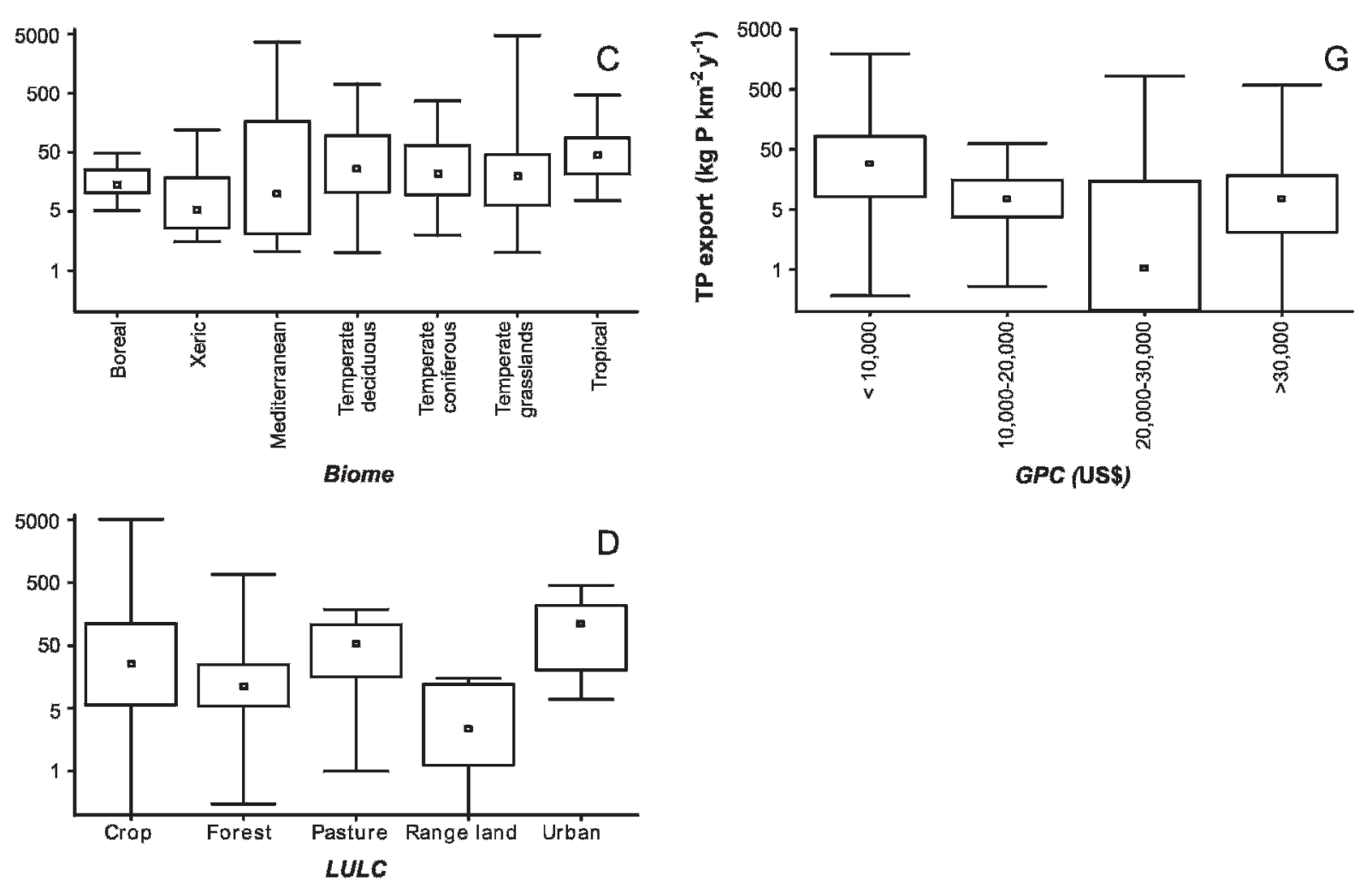

FIG. 3. Box-and-whisker plots of total P (TP) export from catchments that differ with respect to runoff regime (A), soil type (B), biome (C), land use/land cover (LULC) (D), forest type (E), presence of stagnant systems (lentic ecosystems) (F), and soluble reactive $\mathrm{P}$ (SRP) export in catchments that differ with respect to Gross Product per Capita (GPC) (G). Center dots are medians, boxes show $25^{\text {th }}$ and $75^{\text {th }}$ quartiles, whiskers show ranges. In most cases, sufficient data were available only for TP. Categories 
from patterns of $\mathrm{N}$ export (Alvarez-Cobelas et al. 2008) and might be explained by differences between $\mathrm{N}$ and $\mathrm{P}$ biogeochemical transformation pathways (e.g., volatilization and coupled processes of nitrification and denitrification). A pattern of low retention of $\mathrm{P}$ in catchments with high \% stagnant habitat also differs from previous reports (DeVito et al. 1989, Jaworski et al. 1992, Melack 1995, Bruland and Richardson 2006), but global patterns might well differ from local or regional patterns. On a global basis, transformation processes in stagnant surface waters, including formation of particulate organic $\mathrm{P}$ from dissolved fractions, might be responsible for the poor retention of SRP in catchments with high \% stagnant habitat (Sharpley et al. 1995). We treated \% stagnant habitat as a continuous variable, but discrete environmental variables associated with the water bodies (e.g., degree of eutrophication) also might be important factors that influence $\mathrm{P}$ export from catchments with stagnant habitat. For example, eutrophied surface waters could act as sources rather than sinks of $\mathrm{P}$ to rivers. Many other variables (e.g., point vs diffuse origin of nutrients, nutrient loading rates, retention times) will have to be considered simultaneously to derive the detailed $\mathrm{P}$ balances needed to clarify the relationships between stagnant habitat and P export from catchments (Bennett et al. 2001).

We hypothesized that $\mathrm{P}$ export would be lower in catchments where GPC is low than in catchments where GPC is high. However, our results indicate that this hypothesis is incorrect. Variability in $\mathrm{P}$ export was very high in most GPC categories (Fig. 3G). This result suggests that variability in environmental attributes of catchments was independent of socioeconomic factors.

\section{Factors controlling $P$ export}

Our global approach did not produce powerful predictive equations of $\mathrm{P}$ export. The predictive power of $\mathrm{N}$ export models was improved by including $\mathrm{N}$ input data (Alexander et al. 2002), and $\mathrm{P}$ input data might have improved our ability to predict $\mathrm{P}$ export. However, $\mathrm{P}$ input data (point and diffuse wastewater inputs) are not available for many catchments. Our analysis showed that environmental variables that usually are good predictors of $\mathrm{P}$ export at local (Cooke and Prepas 1998, Pieterse et al. 2003) and regional (Behrendt and Opitz 2000, Harris 2001, Alvarez-Cobelas and Angeler 2007) scales were poor predictors of $\mathrm{P}$ export at the global scale (Table 3). Thus, local and regional environmental idiosyncrasies must be taken into account when predicting $\mathrm{P}$ export. Global P export might be better predicted with caseby-case approaches that use local- and regional-scale data at hand (Kalff 1991, Donnelly et al. 1998) than with an integrative analysis based on global data.

The spatial heterogeneity of nutrient sources and sinks increases as spatial scale increases (Gergel 2005). Thus, both heterogeneity and scale of observation must be considered when predicting nutrient export from catchments. Theoretical work suggests that contaminant (including P) delivery to streams takes place at unpredictable spatial and temporal scales, and this unpredictability could lead to underestimation of otherwise acknowledged environmental relationships (Kirchner et al. 2000). Higher spatial resolution at the regional scale and more local analyses are necessary to improve predictability of P export (Smith et al. 2005), and sampling programs with higher temporal resolution are needed to elucidate mechanistic processes (Harris and Heathwaite 2005). Part of the greater explanatory power of local- and regionalscale models probably results from richer environmental information and more accurate measurement at these spatial scales than at the global scale.

We attempted to overcome the problems of heterogeneity and scale by generating multivariate models for catchments in specific runoff, soil, biome, LULC, or GPC categories, but this strategy did not improve model fits (Table 4). Environmental heterogeneity is inherent among catchments in most of these categories, and our ability to predict $\mathrm{P}$ export probably increased or decreased as a function of the environmental heterogeneity among the catchments in each category. Broad categories of runoff regime, soil type, biome, LULC, and GPC, such as those we used, usually are more variable in terms of the number and magnitude of environmental constraints that influence $\mathrm{P}$ export. This variability can increase noise in the data set and affect predictive ability of models, especially when the number of environmental variables available for analysis is low. Given this

were represented if they include $>20$ catchments. Xeric catchments have runoff $<100 \mathrm{~mm} / \mathrm{y}$, whereas mesic catchments have runoff $\geq 100 \mathrm{~mm} / \mathrm{y}$. Boreal biomes include boreal forest/taiga, and xeric biomes include deserts and xeric shrublands. LULC category was determined for catchments with $>80 \%$ of area in a particular landuse category. Insufficient data were available to present TP export in catchments with GPC $<10,000$ US\$. 
limitation, it is noteworthy that population density was a significant predictor in most of our models (Tables 3,4). This result provides additional evidence of the strong impact of humans on the global P cycle (Schlesinger 2001, MacKenzie et al. 2002).

Available models dealing with nutrient export fall into 2 groups, empirical and quasi-empirical (Table 5). Empirical models are derived entirely from a regression approach, whereas quasi-empirical models are developed from data and mechanistic relationships from the literature and are tuned to natural systems via adjustable coefficients (Harrison et al. 2005b). AIC is unavailable for most published models. Thus, a proper comparison among models cannot be made. However, most of the published models are empirical, and cautious use of the adjusted $R^{2}$ as an index of model performance shows that, despite some success when used at local and regional scales (e.g., Vanni et al. 2001, Behrendt and Opitz 2000), their predictive power is not strong at a global scale, perhaps for reasons outlined above. In particular, information on catchment soils and LULC often is loosely reported and hardly quantitative. If the quality of such information could be improved worldwide, the goodness-of-fit of empirical models of $\mathrm{P}$ export might increase, thereby improving the goodness-of-fit of global empirical models. Moreover, models dealing with large catchments (Smith et al. 2003, Harrison et al. 2005a, b) might perform better than models that include more heterogeneous small catchments (Smith et al. 2005).

Quasi-empirical models appeared to explain more variability of $\mathrm{P}$ export than did empirical models (Table 5), and we suggest devoting more effort to quasi-empirical and dynamic models (sensu Harrison et al. 2005b). Examples of this approach include the mixed model for nutrient loading by Smith et al. (1997), the model of $\mathrm{NO}_{3}$ export by Caraco and Cole (1999), and the Riverstrahler dynamic model of nutrient export by Billén et al. (2001). These mechanistic models also should address processes previously overlooked in other modelling efforts. Increased model complexity usually increases ability to predict export, as shown by Alexander et al. (2002) for $\mathrm{N}$ export. For example, buffering capacity of soils (Turner and Rabalais 2003), the size and nature of soil pores and bedrock fractures (Mulholland and Hill 1997), differing erosional patterns (Donnelly et al. 1998), and particle-bound sedimentation and Pimmobilization in the sediment matrix (Frossard et al. 1995) influence P delivery to streams and instream retention through different pathways and with different time lags. In situ bacterial mineralization is another area that has received little attention, despite its obvious influence on the proportions of $P$ fractions 


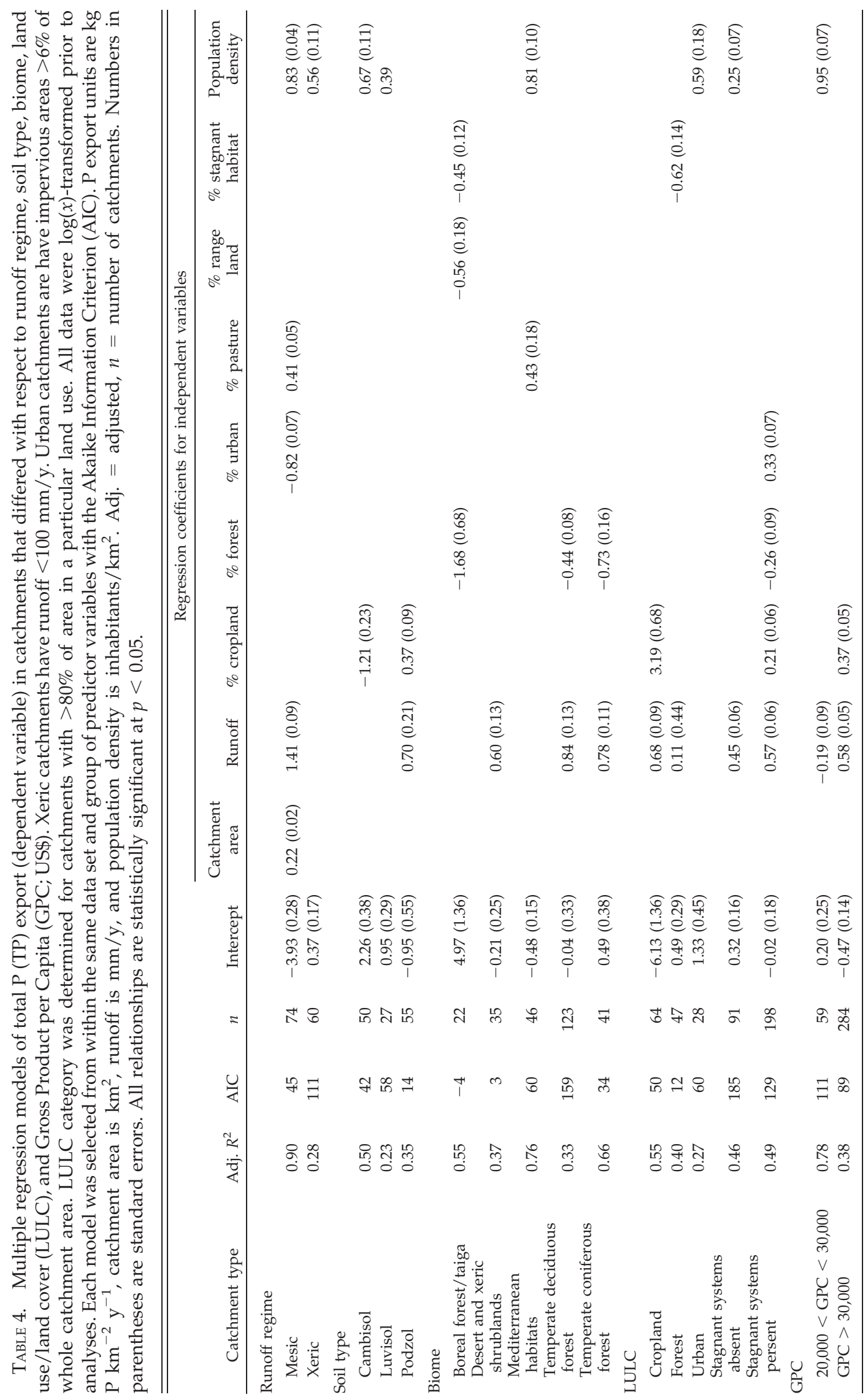


TABle 5. Models of P export (or retention) developed for large areas of the world. Models have been classified by type (table 1 in Harrison et al. 2005b). Empirical models are derived entirely from a regression approach, whereas quasi-empirical models are developed using literature and data-derived relationships and tuned to natural systems with adjustable coefficients. TP $=$ total $\mathrm{P}$, $\mathrm{DOP}=$ dissolved organic $\mathrm{P}, \mathrm{PP}=$ particulate $\mathrm{P}, \mathrm{SRP}=$ soluble reactive $\mathrm{P}, n=$ number of catchments.

\begin{tabular}{|c|c|c|c|c|c|}
\hline Model & Dependent variable (units) & $n$ & Adj. $R^{2}$ & Location & Reference \\
\hline $\begin{array}{l}\text { Quasi-empirical } \\
\text { multivariate }\end{array}$ & DOP export $\left(\mathrm{kg} \mathrm{P} \mathrm{km}^{-2} \mathrm{y}^{-1}\right)$ & 53 & 0.91 & Worldwide & Harrison et al. 2005a \\
\hline $\begin{array}{l}\text { Quasi-empirical } \\
\text { multivariate }\end{array}$ & $\mathrm{TP}$ load $\left(\mathrm{kg} \mathrm{P}^{-1}\right)$ & 381 & 0.82 & USA & Smith et al. 1997 \\
\hline Empirical multivariate & SRP export $\left(\mathrm{mol} \mathrm{P} \mathrm{km}{ }^{-2} \mathrm{y}^{-1}\right)$ & 165 & 0.58 & Worldwide & Smith et al. 2003 \\
\hline Empirical multivariate & SRP export (mol P km $\left.{ }^{-2} \mathrm{y}^{-1}\right)$ & 496 & 0.38 & Worldwide & Smith et al. 2005 \\
\hline Empirical univariate & SRP export $\left(\mathrm{kg} \mathrm{P} \mathrm{ha}^{-1} \mathrm{y}^{-1}\right)$ & 40 & 0.15 & Worldwide & Turner et al. 2003 \\
\hline Empirical multivariate & $\mathrm{TP}$ export $\left(\mathrm{kg} \mathrm{P} \mathrm{km}^{-2} \mathrm{y}^{-1}\right)$ & 183 & 0.73 & Worldwide & This study \\
\hline Empirical multivariate & SRP export $\left(\mathrm{kg} \mathrm{P} \mathrm{km}^{-2} \mathrm{y}^{-1}\right)$ & 111 & 0.60 & Worldwide & This study \\
\hline Empirical multivariate & NonSRP export $\left(\mathrm{kg} \mathrm{P} \mathrm{km}^{-2} \mathrm{y}^{-1}\right)$ & 205 & 0.14 & Worldwide & This study \\
\hline
\end{tabular}

that are exported (Mulholland 2004). Rivers are not simply pipes, and many transformations of $\mathrm{P}$ that impinge on export occur within the channel and could explain some fraction of variability in export models (Meyer and Likens 1979).

Quasi-empirical and dynamic approaches must be developed within a framework that embraces both catchment and instream dynamics and takes into account scales of observation. The nonlinear nature of controlling factors and $\mathrm{P}$ export relationships (Harris 2001) and our poor knowledge of instream P processes (mineralization, uptake by biota, burial in sediments, etc.; Mulholland 2004) currently limit detailed evaluations of global $\mathrm{P}$ export. The definition of environmentally relevant temporal resolution for nutrient export and stoichiometry could further complicate the issue (Harris and Heathwaite 2005, Jordan et al. 2007), particularly during high flows in xeric (Fisher and Minckley 1978) or mesic catchments where the responses can differ between upland and lowland areas of catchments (Bowes et al. 2005). These limitations result in high uncertainty of export estimates of all P fractions (Johnes 2007), even during low flow (Arnscheidt et al. 2007).

Accurate measurement of $\mathrm{P}$ fractions is urgently needed. Despite many efforts over time, measurement error remains a serious drawback for $\mathrm{P}$ studies in aquatic systems (Golterman 2001). Reliable and fast methods to quantify $\mathrm{P}$ fractions, particularly inorganic or organic particle-bound forms, are lacking. This problem impairs the quality of $\mathrm{P}$ export data and leaves a large fraction of $\mathrm{P}$ (nonSRP) unresolved.

In summary, we need to improve current analytical methods and spatial modelling, acquire better knowl- edge of catchment, anthropogenic, and instream processes, and increase temporal frequency of $\mathrm{P}$ export measurements. These steps will constitute the basis for improving predictability of $\mathrm{P}$ export from catchments for which mechanistic models appear to be the preferred approach. This information can be useful for understanding how global biogeochemical cycles respond to the compounded effects resulting from global change.

\section{Acknowledgements}

This paper is a result of projects CGL2006-2346HID, funded by the Spanish Ministry of Science and Innovation, and PAI07-0013-3361, funded by CastillaLa Mancha County. Eva López-Delgado helped us gather data from the web. DGA acknowledges the hospitality of and fruitful discussions with members of the Department of Aquatic Sciences and Assessment while on sabbatical leave at the Swedish University of Agricultural Sciences. Comments by Stephen V. Smith and an anonymous referee greatly improved earlier versions of our manuscript. Robert Hall helped us improve the focus of our study and suggested many formal amendments. Manuel Benítez provided statistical advice.

\section{Literature Cited}

Alexander, R. B., P. J. Johnes, E. W. Boyer, And R. A. Smith. 2002. A comparison of models for estimating the riverine export of nitrogen from large watersheds. Biogeochemistry 57/58:295-339.

Alvarez-Cobelas, M., AND D. G. Angeler. 2007. Exportación de nutrientes en las cuencas hidrográficas de Latinoa- 
mérica: una recopilación. Revista Latinoamericana de Recursos Naturales 3:31-43.

Alvarez-Cobelas, M., D. G. Angeler, and S. SánchezCARRILLO. 2008. Export of nitrogen from catchments: a world-wide analysis. Environmental Pollution 156: 161-169.

Alvarez-Cobelas, M., P. Riolobos, and D. H. Encinas. 2003. Water quality of streams in the Natural Park of Guadarrama River (Madrid, Spain). Report to Madrid Environmental Agency, Madrid, Spain (in Spanish). (Available at: Center for Environmental Sciences-Higher Council of Scientific Research, Serrano 115 dpdo., E28006 Madrid, Spain.)

Arnscheidt, J., P. Jordan, S. Li, S. McCormick, R. McFaul, H. J. McGrogan, M. Neal, and J. T. Sims. 2007. Defining the sources of low-flow phosphorus transfers in complex catchments. Science of the Total Environment 382:1-13.

BEHRENDT, H., AND D. OpITz. 2000. Retention of nutrients in river systems: dependence on specific runoff and hydraulic load. Hydrobiologia 410:111-122.

Bennett, E. A., S. R. Carpenter, and N. F. Caraco. 2001. Human impact on erodable phosphorus and eutrophication: a global perspective. BioScience 51:227-234.

Billén, G., J. Garnier, A. Ficht, And C. Cun. 2001. Modeling the response of water quality in the Seine River Estuary to human activity in its watershed over the last 50 years. Estuaries 24:677-693.

Bowes, M. J., W. A. House, R. A. Hodgkinson, and D. V. LEACH. 2005. Phosphorus-discharge hysteresis during storm events along a river catchment: the River Swale, UK. Water Research 39:751-762.

BRENNER, T. E. 1988. Year 2000: outlook for cleaning products. Journal of the American Organic Chemical Society 65:155-162.

BRuland, G. L., AND C. J. Richardson. 2006. An assessment of the phosphorus retention capacity of wetlands in the Painter Creek watershed, Minnesota, USA. Water, Air, and Soil Pollution 171:169-184.

Burnham, K. P., And D. R. Anderson. 2002. Model selection and multimodel inference. A practical informationtheoretic approach. $2^{\text {nd }}$ edition. Springer, New York.

Campbell, I. C. 1978. Inputs and outputs of water and phosphorus from four Victorian catchments. Australian Journal of Marine and Freshwater Research 29:577-584.

CAIRnS, M. A., AND K. LAJTHA. 2005. Effects of succession on nitrogen export in the West-Central Cascades, Oregon. Ecosystems 8:583-601.

Caraco, N. F., AND Cole, J. J. 1999. Human impact of nitrate export: an analysis using major world rivers. Ambio 28: 167-170.

Caraco, N. F., and J. J. Cole. 2001. Human influence on nitrogen export: a comparison of mesic and xeric catchments. Marine and Freshwater Research 52: 119-125.

CoOKe, S. E., AND E. E. Prepas. 1998. Stream phosphorus and nitrogen export from agricultural and forested watersheds on the Boreal Plain. Canadian Journal of Fisheries and Aquatic Sciences 55:2292-2299.
DeVito, K. J., P. J. Dillon, and B. D. Lazerte. 1989. Phosphorus and nitrogen retention in five Precambrian Shield wetlands. Biogeochemistry 8:185-204.

Donnelly, T. H., C. J. Barnes, R. J. Wasson, A. S. Murray, AND D. L. SHORT. 1998. Catchment phosphorus sources and algal blooms - an interpretative review. Technical Report 18/98. CSIRO Land and Water, Canberra, Australia.

FAO (Food and Agriculture Organization). 2003. The digital soil map of the world, version 3.6. Food and Agriculture Organization of the United Nations. Food and Agriculture Organization, United Nations, Rome, Italy. (Available from: http://www.fao.org/geonetwork/srv/en/ metadata.show? id=14116)

Fisher, S. G., AND W. L. MiNCKLEy. 1978. Chemical characteristics of a desert stream in flash flood. Journal of Arid Environments 1:25-33.

Frossard, E., M. Brossard, M. J. Hedley, and A. Metherell. 1995. Reactions controlling the cycling of $\mathrm{P}$ in soils. Pages 107-137 in H. Tiessen (editor). Phosphorus in the global environment. Scientific Committee on Problems of Environment. Volume 54. John Wiley and Sons, New York.

GARDNER, L. R. 1990. The role of rock weathering in the phosphorus budget of terrestrial watersheds. Biogeochemistry 11:97-110.

Gergel, S. E. 2005. Spatial and non-spatial factors: when do they affect landscape indicators of watershed loading? Landscape Ecology 20:177-189.

Golterman, H. L. 2001. Fractionation and bioavailability of phosphates in lacustrine sediments: a review. Limnetica 20:15-29.

Grove, A. T., AND O. RACKHAM. 2001. The nature of Mediterranean Europe: an ecological history. Yale University Press, New Haven, Connecticut.

Harris, G. P. 2001. Biogeochemistry of nitrogen and phosphorus in Australian catchments, rivers and estuaries: effects of land use and flow regulation and comparisons with global patterns. Marine and Freshwater Research 52:139-149.

Harris, G. P., and A. L. Heathwaite. 2005. Inadmissible evidence: knowledge and prediction in land and riverscapes. Journal of Hydrology 304:3-19.

Harrison, J. A., N. Caraco, and S. P. Seitzinger. 2005a. Global patterns and sources of dissolved organic matter export to the coastal zone: results from a spatially explicit, global model. Global Biogeochemical Cycles 19, GB4S04. doi:10.1029/2005GB002480.

Harrison, J. A., S. P. Seitzinger, A. F. Bouwman, N. F. Caraco, A. W. H. Beusen, and C. J. Vörösmarty. 2005b. Dissolved inorganic phosphorus export to the coastal zone: results from a spatially explicit, global model. Global Biogeochemical Cycles 19, GB4S03. doi:10.1029/2004GB002357.

House, W. A., D. Leach, M. S. Warwick, B. A. Whitton, S. N. Pattinson, G. Ryland, A. Pinder, J. Ingram, J. P. Lishman, S. M. Smith, E. RigG, and F. H. Denison. 1997. Nutrient transport in the Humber Rivers. Science of the Total Environment 194/195:303-320. 
Howarth, R. W., H. Jensen, R. Marino, and H. Postma. 1995. Transport to and processing of phosphorus in nearshore and oceanic waters. Pages 323-345 in H. Tiessen (editor). Phosphorus in the global environment. Scientific Comittee on Problems of Environment. Volume 54. John Wiley and Sons, New York.

International Monetary Fund. 2000. The World Economic Outlook (WEO) Database April 2000. Gross Domestic Product Per Capita at Current Prices in US\$. International Monetary Fund, Washington, DC. (Available from: http://www.imf.org/external/pubs/ft/weo/ 2000/01/data/index.htm)

Jaworski, N. A., P. M. Groffman, A. A. Keller, and J. C. PRAGER. 1992. A watershed nitrogen and phosphorus balance: the upper Potomac River basin. Estuaries 15: 83-95.

JoHnes, P. J. 1996. Evaluation and management of the impact of land use change on the nitrogen and phosphorus load delivered to surface waters: the export coefficient modelling approach. Journal of Hydrology 183:323-349.

JoHNES, P. J. 2007. Uncertainties in annual riverine phosphorus load estimation: impact of load estimation methodology, sampling frequency, baseflow index and catchment population density. Journal of Hydrology 332: 241-258.

Jordan, P., A. Arnscheidt, H. McGrogan, And S. McCormick. 2007. Characterising phosphorus transfers in rural catchments using a continuous bank-side analyser. Hydrology and Earth System Sciences 11:372-381.

KALFF, J. 1991. The utility of latitude and other environmental factors as predictors of nutrients, biomass and production in lakes worldwide: problems and alternatives. Verhandlungen der Internationalen Vereinigung für theoretische und angewandte Limnologie 24: 1235-1239.

Kirchner, J. W., X. Feng, and C. Neal. 2000. Fractal stream chemistry and its implications for contaminant transport in catchments. Nature 403:524-527.

Kronvang, B., L. M. SvendSEn, J. P. Jensen, And J. Dörge. 1999. Scenario analysis of nutrient management at the river basin scale. Hydrobiologia 410:207-212.

KRUG, A. 1993. Drainage history and land use pattern of a Swedish river system - their importance for understanding nitrogen and phosphorus load. Hydrobiologia 251:285-296.

Legendre, P., And L. Legendre. 1998. Numerical ecology. $2^{\text {nd }}$ edition. Elsevier, Amsterdam, The Netherlands.

Lesack, L. F. W., R. E. Hecky, and J. M. Melack. 1984. Transport of carbon, nitrogen and phosphorus, and major solutes in the Gambia River, West Africa. Limnology and Oceanography 29:816-830.

Lewis, W. M., JR., And W. Wurtsbaugh. 2008. Control of lacustrine phytoplankton by nutrients: erosion of the phosphorus paradigm. International Review of Hydrobiology 93:446-465.

Likens, G. E., F. H. Bormann, R. S. Pierce, J. S. Eaton, and N. M. JoHnson. 1977. Biogeochemistry of a forested ecosystem. Springer-Verlag, New York.
Lovett, G. M., K. C. Weathers, and W. V. Sobczak. 2000. Nitrogen saturation and retention in forested watersheds of the Catskill mountains, New York. Ecological Applications 10:73-84.

MacKenzie, F. T., L. M. Ver, and A. Lerman. 2002. Centuryscale nitrogen and phosphorus controls of the carbon cycle. Chemical Geology 190:13-32.

Mander, Ü., A. Kull, V. KuUsemets, and T. Tamm. 2000. Nutrient runoff dynamics in a rural catchment: influence of land-use changes, climatic fluctuations and ecotechnological measures. Ecological Engineering 14: 405-417.

MarchetTI, R., AND N. VernA. 1992. Quantification of the phosphorus and nitrogen loads in the minor rivers of the Emilia-Romagna coast (Italy). A methodological study on the use of theoretical coefficients in calculating the loads. Science of the Total Environment, Supplement 1992:315-336.

McGechan, M. B., And D. R. Lewis. 2002. Soil and water sorption of phosphorus by soil, Part 1: principles, equations and models. Biosystem Engineering 82:1-24.

McKeE, L. J., AND B. D. EyRE. 2000. Nitrogen and phosphorus budgets for the sub-tropical Richmond River catchment, Australia. Biogeochemistry 50:207-239.

McKergow, L. A., D. M. Weaver, I. P. Prosser, R. B. Grayson, AND A. E. G. REED. 2003. Before and after riparian management: sediment and nutrient exports from a small agricultural catchment, Western Australia. Journal of Hydrology 270:253-272.

MelaCK, J. M. 1995. Transport and transformations of P, fluvial and lacustrine ecosystems. Pages 245-254 in $\mathrm{H}$. Tiessen (editor). Phosphorus in the global environment. Scientific Committee on Problems of Environment. Volume 54. John Wiley and Sons, New York.

Meyвеск, M. 1982. Carbon, nitrogen, and phosphorus transport by world rivers. American Journal of Science 282:401-450.

Meyer, J. L., AND G. E. Likens. 1979. Transport and transformation of phosphorus in a forest stream ecosystem. Ecology 60:1255-1269.

Morse, C. C., A. D. Huryn, And C. Cronan. 2003. Impervious surface area as a predictor of the effects of urbanization on stream insect communities in Maine, U.S.A. Environmental Monitoring and Assessment 89:95-127.

Moss, A. J., G. E. Rayment, N. Reilly, and E. K. Best. 1992. A preliminary assessment of sediment and nutrient exports from Queensland coastal catchments. Queensland Department of Environment and Heritage, Brisbane, Australia. (Available from: https://www.epa.qld. gov.au/publications/p00334aa.pdf).

Mullholland, P. J. 2004. The importance of in-stream uptake for regulating stream concentrations and outputs of $\mathrm{N}$ and $\mathrm{P}$ from a forested watershed: evidence from long-term chemistry records for Walker Branch Watershed. Biogeochemistry 70:403-426.

Mulholland, P. J., AND W. R. HiLl. 1997. Seasonal patterns in streamwater nutrient and dissolved organic carbon concentrations: separating catchment flow path and instream effects. Water Resources Research 33:1297-1306. 
Naiman, R. J., And J. R. Sibert. 1978. Transport of nutrients and carbon from the Nanaimo River to its estuary. Limnology and Oceanography 23:1183-1193.

Nelson, P. N., E. Cotsaris, and J. M. OAdes. 1996. Nitrogen, phosphorus, and organic carbon in streams draining two grazed catchments. Journal of Environmental Quality 25:1221-1229.

Neter, J., M. H. Kutner, C. J. Nachtsheim, and W. WasserMAN. 1996. Applied linear statistical models. Irwin, Chicago, Illinois.

Nhapi, I., Z. Hoko, M. A. Siebel, and H. J. Gijzen. 2002. Assessment of the major water and nutrient flows in the Chivero catchment area, Zimbabwe. Physics and Chemistry of the Earth 27:783-792.

Nixon, S. W., S. L. Granger, And B. L. Nowicki. 1995. An assessment of the annual mass balance of carbon, nitrogen, and phosphorus in Narragansett Bay. Biogeochemistry 31:15-61.

Norton, M. M., AND T. R. Fisher. 2000. The effects of forest on stream water quality in two coastal plain watersheds of the Chesapeake Bay. Ecological Engineering 14: 337-362.

Olson, D. M., E. Dinerstein, E. D. Wikramanayake, N. D. Burgess, G. V. N. Powell, E. C. Underwood, J. A. D'amico, I. Itoua, H. E. Strand, J. C. Morrison, C. J. Loucks, T. F. Allnutt, T. H. Ricketts, Y. Kura, J. F. Lamoreux, W. W. Wettengel, P. Hedao, and K. R. KASSEM. 2001. Terrestrial ecoregions of the world: a new map of life on Earth. BioScience 51:933-938. (Available from: http://www.worldwildlife.org/ science/data/item6373.html)

Oyarzún, C. E., R. Godoy, and A. Sepúlveda. 1998. Water and nutrient fluxes in a cool temperate rainforest at the Cordillera de la Costa in southern Chile. Hydrological Processes 12:1067-1077.

Peterson, B. J., T. Corliss, K. Kriet, and J. E. Hobbie. 1992. Nitrogen and phosphorus concentrations and export for the upper Kuparuk River on the North Slope of Alaska in 1980. Hydrobiologia 240:61-69.

Pieterse, N. M., W. Bleuten, and S. E. Jørgensen. 2003. Contribution of point sources and diffuse sources to nitrogen and phosphorus loads in lowland river tributaries. Journal of Hydrology 271:213-225.

Postel, S. 1992. Last oasis: facing water scarcity. W. W. Norton and Co., New York.

Prairie, Y. T., AND D. F. BiRD. 1989. Some misconceptions about the spurious correlation problem in the ecological literature. Oecologia (Berlin) 81:285-288.

Probst, J. L. 1985. Nitrogen and phosphorus exportation in the Garonne basin (France). Journal of Hydrology 76: 281-305.

Provini, A., G. Crosa, and R. Marchetti. 1992. Nutrient export from the Po and Adige river basins over the last 20 years. Science of the Total Environment, Supplement 1992:291-313.

Russell, M. A., D. E. Walling, B. W. Webb, and R. Bearne. 1998. The composition of nutrient fluxes from contrasting UK river basins. Hydrological Processes 12:1461-1482.
SChINDLER, D. W. 2006. Recent advances in the understanding and management of eutrophication. Limnology and Oceanography 51:356-363.

Schindler, D. W., R. E. Hecky, D. L. Findlay, M. P. Stanton, B. R. Parker, M. J. Paterson, K. G. Beaty, M. Lyng, and S. E. M. KasLAN. 2008. Eutrophication of lakes cannot be controlled by reducing nitrogen input: results of a 37year whole-ecosystem experiment. Proceedings of the National Academy of Sciences of the United States of America 105:11254-11258.

Schlesinger, W. H. 2001. Biogeochemistry. An analysis of global change. $2^{\text {nd }}$ edition. Academic Press, San Diego, California.

Sharpley, A. N., S. J. Smith, O. R. Jones, W. A. Berg, and G. A. Coleman. 1992. The transport of bioavailable phosphorus in agricultural runoff. Journal of Environmental Quality 21:30-35.

Sharpley, A. N., M. J. Hedley, E. Sibbesen, A. HillbrichtILKOWSKA, W. A. House, And L. RYszKowski. 1995. Phosphorus transfers from terrestrial to aquatic ecosystems. Pages 171-200 in H. Tiessen (editor). Phosphorus in the global environment. Scientific Committee on Problems of Environment. Volume 54. John Wiley and Sons, New York.

Siegel, S., AND N. J. CASTELlan. 1988. Nonparametric statistics for the behavioral sciences. $2^{\text {nd }}$ edition. McGraw-Hill, New York.

Smith, R. A., G. E. Schwarz, And R. B. Alexander. 1997. Regional interpretation of water-quality monitoring data. Water Resources Research 33:2781-2798.

Smith, S. V., D. P. SWANEy, R. W. BudDEMEIER, M. R. ScARSBROOK, M. A. Weatherhead, C. Humborg, H. Eriksson, and F. HANNERZ. 2005. River nutrient loads and catchment size. Biogeochemistry 75:83-107.

Smith, S. V., D. P. Swaney, L.Talaue-McManus, J. D. Bartley, P. T. Shandey, C. J. Mclaughlin, V. C. Dupra, C. J. Crossland, R. W. Buddemeier, B. A. Maxwell, and F. WulfF. 2003. Humans, hydrology, and the distribution of inorganic nutrient loading to the ocean. BioScience 53: 235-245.

Stålnacke, P., A. Grimvall, K. Sundblad, and A. Tonderski. 1999. Estimation of riverine loads of nitrogen and phosphorus to the Baltic Sea, 1970-1993. Environmental Monitoring and Assessment 58:173-200.

Stow, C. A., M. E. Borsuk, and D. W. Stanley. 2001. Longterm changes in watershed nutrient inputs and riverine exports in the Neuse River, North Carolina. Water Research 35:1489-1499.

Turner, R. E., And N. N. Rabalais. 2003. Linking landscape and water quality in the Mississipi River basin for 200 years. BioScience 53:563-572.

Turner, R. E., N. N. Rabalais, D. Justic, And Q. Dortch. 2003. Global patterns of dissolved N, P and Si in large rivers. Biogeochemistry 6:297-317.

Vanni, M. J., W. H. Renwick, J. L. Headworth, J. D. Auch, AND M. H. Schaus. 2001. Dissolved and particulate nutrient flux from three adjacent agricultural watersheds: a five-year study. Biogeochemistry 54:85-114.

Vollenweider, R. A. 1968. Scientific fundamentals of the eutrophication of lakes and flowing waters with 
particular reference to nitrogen and phosphorus as factors in eutrophication. Organisation for Economic Co-operation and Development, Paris, France.

Voutsa, D., E. Manoli, C. Samara, M. Sofoniou, and I. Stratis. 2001. A study of surface water quality in Macedonia, Greece: speciation of nitrogen and phosphorus. Water, Air and Soil Pollution 129:13-32.

Whittingham, M. J., P. A. Stephens, R. B. Bradbury, and R. P. Freckleton. 2006. Why do we still use stepwise modelling in ecology and behaviour? Journal of Animal Ecology 75:1182-1189.
Williams, M. R., and J. M. Melack. 1997a. Atmospheric deposition, mass balances, and processes regulating streamwater solute concentrations in mixed-conifer catchments of the Sierra Nevada, California. Biogeochemistry 37:111-144.

Williams, M. R., AND J. M. Melack. 1997b. Solute export from forested and partially deforested catchments in the central Amazon. Biogeochemistry 38:67-102.

Received: 18 November 2008

Accepted: 29 June 2009 